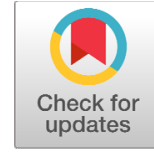

Received: Nov 29, 2021

Revised: Dec 8, 2021

Accepted: Dec 9, 2021

*Corresponding author

Beob Gyun Kim

Department of Animal Science and

Technology, Konkuk University,

Seoul 05029, Korea

Tel: +82-2-2049-6255

E-mail: beobgyun@konkuk.ac.kr

Copyright @ $\odot 2021$ Korean Society of Animal Science and Technology.

This is an Open Access article distributed under the terms of the Creative Commons Attribution Non-Commercial License (http://creati vecommons.org/licenses/by-nc/4.0) which permits unrestricted non-commercial use, distribution, and reproduction in any medium, provided the original work is properly cited.

ORCID

Hyunwoong Jo

https://orcid.org/0000-0002-3837-6041

Sang Chul Lee

https://orcid.org/0000-0002-9341-3255

Beob Gyun Kim

https://orcid.org/0000-0003-2097-717X

\section{Estimation of growth model parameters for novel mini-pig breeds}

\author{
Hyunwoong Jo ${ }^{1}$, Sang Chul $\mathrm{Lee}^{2}$ and Beob Gyun Kim${ }^{1 *}$ \\ ${ }^{1}$ Department of Animal Science and Technology, Konkuk University, Seoul 05029, Korea \\ ${ }^{2}$ Cronex Co., Ltd., Hwaseong 18525, Korea
}

\begin{abstract}
The present work aimed to develop growth curve models for two mini-pig breeds: an M-Pig ${ }^{\circledR}$ breed originating from Korean Jeju Island's native pigs (Cronex) and Micro-pig ${ }^{\circledR}$ (Medi Kinetics). A total 680 body weight (BW) data for the M-Pig ${ }^{\circledR}$ ranging from 0.8 to $63.2 \mathrm{~kg} \mathrm{BW}$ for 40 animals were collected from birth to 52 weeks of age. A total of $36 \mathrm{BW}$ and age data for the Micro-Pig ${ }^{\circledR}$ ranging from 0.35 to $33.5 \mathrm{~kg} \mathrm{BW}$ and 0 to 96 weeks, respectively, were obtained from 20 experiments in the literature. Two different nonlinear growth curves models employed in the present work were Gompertz and Logistic models. Estimated BW growth models of $\mathrm{M}-\mathrm{Pig}^{\circledR}$ as a function of age (week) were: Gompertz model BW, $\mathrm{kg}=64.57 \times e^{-3.21 \times e^{-0.06 t}}$ with $\mathrm{R}^{2}=0.976$ and Logistic model $\mathrm{BW}, \mathrm{kg}=57.94 \times\left(1+12.33 \times \mathrm{e}^{-0.11 t}\right)^{-1}$ with $\mathrm{R}^{2}=0.969$. Estimated BW growth models of Micro-pig $^{\circledR}$ as a function of age (week) were: Gompertz model BW, $\mathrm{kg}=31.47 \times$ $e^{-2.10 \times e^{-0.07 t}}$ with $\mathrm{R}^{2}=0.793$ and Logistic model BW, $\mathrm{kg}=30.45 \times\left(1+4.76 \times e^{-0.10 t}\right)^{-1}$ with $R^{2}=0.775$. In conclusion, the BW growth curve of mini-pigs fitted better in Gompertz models than in Logistic models. The growth curves for mini-pigs developed in the present work may be used for BW gain prediction in future research employing mini-pig breeds.
\end{abstract}

Keywords: Growth curve, Miniature pig, Swine

\section{INTRODUCTION}

Swine are widely used as models for human due to the similarities in anatomy of the digestive systems and physiologic characteristics [1]. Mini-pigs are a useful laboratory animal for safety evaluation of pharmaceuticals, organ transplantation studies and nutritional studies $[2,3]$. In contrast to commercial pigs selected for fast growth, mini-pigs grow relatively slowly and their mature body weight (BW) is less than commercial pigs. Due to the relatively small BW, mini-pigs have many advantages in general managements and animal handlings. Mini-pigs can be used in swine nutrition studies with limited quantity of test ingredients and in experiments requiring surgeries such as ileal T-cannula insertion for ileal digestibility assessment [4-6].

Information on growth potential of experimental animals is important in planning and designing animal experiments as well as in optimizing animal production efficiencies. Many studies for modeling growth curves of various animals have been conducted [7-9]. However, information on growth curves of mini-pig breeds is very limited. Therefore, the present study 
Competing interests

No potential conflict of interest

relevant to this article was reported.

Funding sources

This work was supported by the National Research Foundation of Korea (NRF) grant funded by the Korea government (MSIP) (No. 2016R1A2B2015665)

\section{Acknowledgements} Not applicable.

\author{
Availability of data and material \\ Upon reasonable request, the \\ datasets of this study can be \\ available from the corresponding \\ author. \\ Authors' contributions \\ Conceptualization: Jo H, Kim BG. \\ Data curation: Jo $\mathrm{H}$, Lee SC. \\ Formal analysis: Lee SC. \\ Methodology: Kim BG. \\ Validation: Kim BG. \\ Investigation: Jo $\mathrm{H}$, Lee SC. \\ Writing - original draft: Jo $\mathrm{H}$ \\ Writing - review \& editing: Lee SC, \\ Kim BG.
}

Ethics approval and consent to participate

This article does not require IRB/ IACUC approval because there are no human and animal participants. aimed to develop growth curve models for novel mini-pig breeds.

\section{MATERIALS AND METHODS}

Two mini-pig breeds used in the present work were an M-Pig ${ }^{\circledR}$ breed originated from Korean Jeju Island's native pigs (Cronex, Hwaseong, Korea) and Micro-pig (Medi Kinetics, Pyeongtaek, Korea). The M-Pig ${ }^{\oplus}$ is a selected Jeju Island's native pig breed with slow BW growth rate and the Micro-pig is a crossbreed developed by breeding white gilts selected from cross breeds (Korean native pig, Yucatan mini-pig, Vietnamese pot-bellied pig, and Pygmy pig) with Meishan boars.

For the growth analysis, BW data for M-Pig ${ }^{\oplus}$ (Cronex) were obtained from Cronex and data for Micro-pig ${ }^{\oplus}$ (Micro-pig ${ }^{\circledR}$; Medi Kinetics) were from 20 published experiments. A total 680 BW data for the M-Pig ranging from 0.8 to $63.2 \mathrm{~kg} \mathrm{BW}$ for 40 animals were collected from birth to 52 weeks of age and a total of $36 \mathrm{BW}$ and age data (mean values representing 128 pigs) for the Micro-pig ${ }^{\oplus}$ ranging from 0.35 to $33.5 \mathrm{~kg}$ BW were obtained from birth to 96 weeks.

The growth curves of two different mini-pig breeds by nonlinear regression were generated using the NLIN procedure of SAS (SAS Institute, Cary, NC, USA). The growth models employed in this work were Gompertz and Logistic models with 3 parameters in the equation [10,11]:

$$
\begin{aligned}
& W t=A e^{-b e^{-k t}} \\
& W t=A\left(1+b e^{-k t}\right)^{-1}
\end{aligned}
$$

where $W t$ is the $\mathrm{BW}$ at $t$ week; $A$ is the mature weight; $b$ is the growth ratio; $k$ is the maturing rate; and $e$ is the natural logarithm. The models were compared using corrected $\mathrm{R}^{2}$ which is calculated by MEANS procedure of SAS. Based on the estimated growth parameters, the characteristics of growth curve were induced, that are age at point of inflection, gain at inflection and weight at inflection. In the Gompertz model, the age at point of inflection $\left(t_{i}\right)$, weight at inflection $\left(W t_{i}\right)$ and gain at inflection $(\partial W t / \partial t)$ are [12]:

$$
t_{i}=\left(\log _{e} b\right) / k, W t_{i}=A / e \text { and } d y_{i} / d t_{i}=k b w_{t i} e^{-k t}, \text { respectively. }
$$

In the Logistic model,

$$
t_{i}=\left(\log _{e} b\right) / k, W t_{i}=A / 2 \text { and } d y_{i} / d t_{i}=A b k e^{k t i} /\left(e^{k t i}+b\right)^{2} \text {, respectively. }
$$

The inflection point is the week at which the slope of the growth curve becomes maximum. In other words, the second derivative of the time of models used for growth curve estimation was calculated to be zero. 


\section{RESULTS AND DISCUSSION}

The Gompertz model fitted better than the Logistic model in both mini-pig breeds based on determination coefficients (Table 1). This observation implies that a Logistic model tends to estimate upward and downward for early and mature weight, respectively [13]. Except for the maturing rate, the mature BW and growth rate of M-pig ${ }^{\circledR}$ were higher than in Micro-pig. This difference can be partly explained by different breeding methods. The M-pig ${ }^{\oplus}$ breed was developed by selecting Korean Jeju Island's native pigs with slow BW growth rate, whereas the Micro-pig ${ }^{\curvearrowleft}$ was developed by breeding white gilts selected from cross breeds (Korean native pig, Yucatan mini-pig, Vietnamese pot-bellied pig, and Pygmy pig) with Meishan boars. All characteristics at inflection point of M-pig ${ }^{\circledast}$ were greater than those of Micro-pig ${ }^{\oplus}$ (Table 2).

Graphical comparisons of the growth models for M-pig and Micro-pig ${ }^{\circledast}$ are illustrated in Figs. 1 and 2, respectively. Apparently, mature BW of both mini-pig breeds are less than that of conventional Korean native breeds and crossbreds. Mature BW of the crossbred between Korean native boars and Landrace sows has been reported to be $179.7 \mathrm{~kg}$ [14]. In addition, the mature BW of Korean Jeju Isaland's native pigs and a crossbred between Korean natvie sows and Duroc are 154.3 and 170.8, respectively [15]. Considering the small or optimal size, these mini-pig breeds are useful for pharmaceutical evaluation and organ transplantation research. The mini-pig breeds can also be used for swine nutrition experiments when the quantity of a test feedstuff is not sufficient for experimentation using commercial pigs or the large size of commercial pigs is a limiting factor. An accurate determination of amino acid digestibility of

Table 1. Estimates of growth curve parameters for mini-pigs using Gompertz and Logistic models as a function of age (week)

\begin{tabular}{cccccc}
\hline \multirow{2}{*}{ Breed } & Growth model & \multicolumn{3}{c}{ Parameters } & \multirow{2}{*}{$\mathrm{R}^{2}$} \\
\cline { 3 - 5 } & & $\boldsymbol{A} \pm \mathrm{SE}$ & $\boldsymbol{b} \pm \mathrm{SE}$ & $\boldsymbol{k} \pm \mathrm{SE}$ & \\
\hline M-Pig $^{\circledR}$ & Gompertz $^{1)}$ & $64.57 \pm 0.92$ & $3.21 \pm 0.06$ & $0.06 \pm 0.00$ & 0.976 \\
& Logistic $^{2)}$ & $57.94 \pm 0.58$ & $12.33 \pm 0.49$ & $0.11 \pm 0.00$ & 0.969 \\
\hline Micro-pig $^{\circledR}$ & Gompertz & $31.47 \pm 1.73$ & $2.10 \pm 0.44$ & $0.07 \pm 0.01$ & 0.793 \\
& Logistic & $30.45 \pm 1.56$ & $4.76 \pm 1.71$ & $0.10 \pm 0.02$ & 0.775 \\
\hline
\end{tabular}

${ }^{1)}$ Gompertz model: body weight, $\mathrm{kg}=A e^{-b e^{-h t}}$.

${ }^{2)}$ Logistic model: body weight, $\mathrm{kg}=A\left(1+b e^{-k^{k}}\right)^{-1}$.

$A$, mature body weight; $b$, growth ration; $k$, maturing rate.

Table 2. Characteristics at inflection point on growth curves using Gompertz and Logistic models for mini-pigs as a function of age

\begin{tabular}{ccccc}
\hline Breed & Growth model & $\begin{array}{c}\text { Age at point of } \\
\text { inflection (week) }\end{array}$ & $\begin{array}{c}\text { Gain at inflection } \\
(\mathrm{kg} / \text { week })\end{array}$ & $\begin{array}{c}\text { Body weight at } \\
\text { inflection }(\mathrm{kg})\end{array}$ \\
\hline $\mathrm{M}-\mathrm{Pig}^{\circledR}$ & Gompertz & 18.9 & 1.47 & 23.8 \\
& Logistic & 23.1 & 1.58 & 29.0 \\
\hline Micro-pig $^{\circledR}$ & Gompertz & 11.2 & 0.77 & 11.6 \\
& Logistic & 16.3 & 0.73 & 15.2 \\
\hline
\end{tabular}


Gompertz model

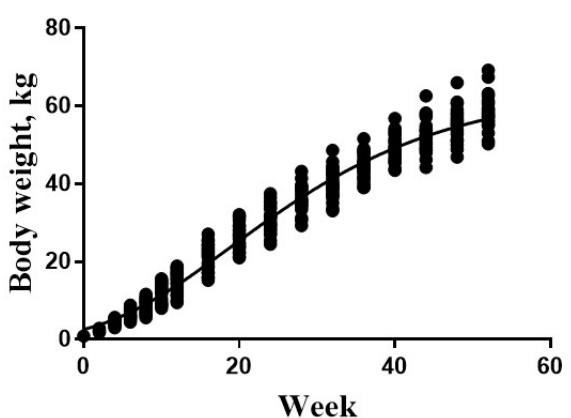

Logistic model

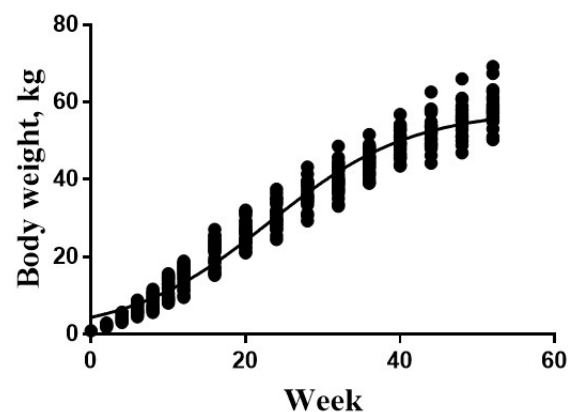

Fig. 1. Body weight growth models of $\mathrm{M}-\mathrm{Pig}^{\circledR}$ as a function of age. Gompertz model: body weight, $\mathrm{kg}=$ $64.57 \times e^{-3.21 \times e^{-0.06 t}}$ with $\mathrm{R}^{2}=0.976$. Logistic model: body weight, $\mathrm{kg}=57.94\left(1+12.33 e^{-0.11}\right)^{-1}$ with $\mathrm{R}^{2}$ $=0.969$.

Gompertz model

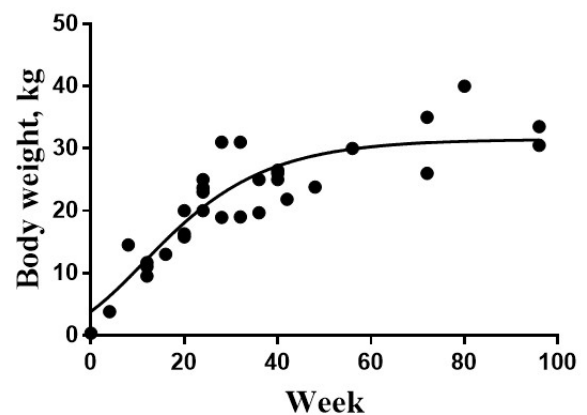

Logistic model

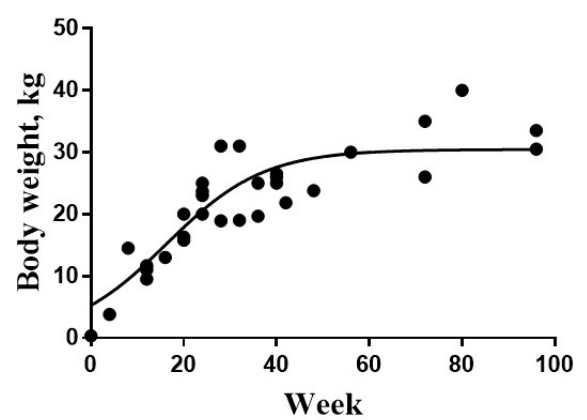

Fig. 2. Body weight growth models of Micro-pig ${ }^{\circledR}$ (Medi Kinetics) as a function of age. Gompertz model: body weight, $\mathrm{kg}=31.47 \times e^{-2.10 \times e^{-0.07 t}}$ with $\mathrm{R}^{2}=0.793$. Logistic model: body weight, $\mathrm{kg}=30.45 \times(1+4.76$ $\times e^{-0.10)^{-1}}$ with $R^{2}=0.775$.

swine diets requires surgical insertion of $\mathrm{T}$-cannula into the terminal ileum $[5,6,16]$, which has been used in many experiments employing commercial pigs [4,6,15-18]. However, a T-cannula equipped in commercial growing pigs does not last more than three to four months. The mini-pigs breeds are useful for overcoming the limitation of commercial pigs. The information provided in the present work can be used for designing and planning swine nutrition research.

In conclusion, modeling of growth curves for a novel mini-pig breed with differennt growth models is a useful tool for designing experiments employing the mini-pig breed as well as for general management of these animals. Additionally, the novel mini-pig breed can be used in experiments for a longer period compared with commercial pigs.

\section{REFERENCES}

1. Brandt H, Möllers B, Glodek P. Prospects for a genetically very small minipig. Scand J Lab Anim Sci. 1998;25 Suppl 1:93. 
2. Copper DKC, Ye Y, Rolf LL Jr, Zuhdi N. The pig as potential organ donor for man. In: Cooper DKC, Kemp E, Reemtsma K, White DJG, editors. Xeno-transplantation. Berlin: Springer; 1991. p. 481-500.

3. Lee JY, Cho SB, Kim YY, Ohh SJ. Effect of gamma irradiation and autoclaving on sterilization and amino acids digestibility of diets for specific pathogen free mini-pigs containing either soybean meal or whey protein. Livest Sci. 2012;149:201-7. https://doi.org/10.1016/j.livsci.2012. 07.010

4. Son AR, Park CS, Park KR, Kim BG. Amino acid digestibility in plant protein sources fed to growing pigs. Asian-Australas J Anim Sci. 2019;32:1745-52. https://doi.org/10.5713/ajas.19. 0037

5. Lee SA, Ahn JY, Son AR, Kim BG. Standardized ileal digestibility of amino acids in cereal grains and co-products in growing pigs. Asian-Australas J Anim Sci. 2020;33:1148-55. https://doi.org/10.5713/ajas.19.0449

6. Sung JY, Ji SY, Kim BG. Amino acid and calcium digestibility in hatchery byproducts fed to nursery pigs. Anim Feed Sci Technol. 2020;270:114703. https://doi.org/10.1016/j.anifeedsci. 2020.114703

7. Menchaca MA, Chase CC Jr, Olson TA, Hammond AC. Evaluation of growth curves of Brahman cattle of various frame sizes. J Anim Sci. 1996;74:2140-51. https://doi.org/10.2527/ 1996.7492140x

8. Şengül T, Kiraz S. Non-linear models for growth curves in large white turkeys. Turk J Vet Anim Sci. 2005;29:331-7.

9. Köhn F, Sharifi AR, Simianer H. Modeling the growth of the Goettingen minipig. J Anim Sci. 2007;85:84-92. https://doi.org/10.2527/jas.2006-271

10. Gompertz B. On the nature of the function expressive of the law of human mortality, and on a new mode of determining the value of life contingencies. London, UK: Philosophical Transactions of the Royal Society of London; 1825.

11. Robertson TB. On the normal rate of growth of an individual, and its biochemical significance. Arch Entwicklung Org. 1908;25:581-614. https://doi.org/10.1007/BF02163864

12. Son AR, Jo H, Park KR, Kim BG. Comparison of Compertz and logistic models in estimating the growth of leptin-deficient (ob/ob) mice and wild-type mice fed an in-house prepared high -fat diet. Am J Anim Vet Sci. 2019;14:1-6. https://doi.org/10.3844/ajavsp.2019.1.6

13. Brown JE, Fitzhugh HA Jr, Cartwright TC. A comparison of nonlinear models for describing weight-age relationships in cattle. J Anim Sci. 1976;42:810-8. https://doi.org/10.2527/jas1976. 424810x

14. Cho YM, Choi BH, Kim TH, Lee JW, Lee JE, Oh SJ, et al. A study on estimation of individual growth curve parameters and their relationships with meat quality traits of crossbred between Korean native boars and landrace sows. J Anim Sci Technol. 2004;46: 503-8. https://doi.org/10.5187/JAST.2004.46.4.503

15. Won JI, Lee KS, Kim SD, Yoon HB, Jeon SK, Yoon JH, et al. Estimation of growth curve parameters for evaluation of growth characteristics of purebred Korean native pigs and 
crossbred between Korean native sows and Duroc boars. J Agric Life Sci. 2014;48:155-63. https://doi.org/10.14397/jals.2014.48.4.155

16. Stein HH, Sève B, Fuller MF, Moughan PJ, de Lange CFM. Invited review: amino acid bioavailability and digestibility in pig feed ingredients: terminology and application. J Anim Sci. 2007;85:172-80. https://doi.org/10.2527/jas.2005-742

17. Kim BG, Liu Y, Stein HH. Effects of ileal digesta collection time on standardized ileal digestibility of amino acids in corn, soybean meal, and distiller's dried grains with solubles fed to growing pigs. J Anim Sci. 2017;95:789-98. https://doi.org/10.2527/jas.2016.1082

18. Kim BG, Lee SA, Park KR, Stein HH. At least 3 days of adaptation are required before indigestible markers (chromium, titanium, and acid insoluble ash) are stabilized in the ileal digesta of $60-\mathrm{kg}$ pigs, but values for amino acid digestibility are affected by the marker. J Anim Sci. 2020;98:skaa027. https://doi.org/10.1093/jas/skaa027 